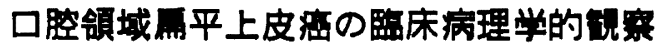

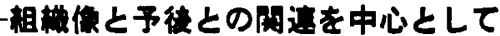

\author{
佐野和生・井口次夫・中村仁昭・北村胃 \\ 佐↔木元買*・高桶 弘**
}

\section{Clinicopathological observation of oral squamous cell carcinoma Correlation between histological findings and prognosis -}

\author{
Kazuo Sano - Tsugio Inokuchi - Hitoaki Nakamura - Akira Kitamura \\ Motomasa SASAKI* = Hiroshi TAKAHASHI**
}

\begin{abstract}
Forty-six patients with oral squamous cell carcinoma were reviewed clinicopathologically. A histological classification was performed on the initial biopsies prior to treatment, and the correlation between histological factors and prognosis was investigated.

Four different histological factors (Differentiation, Nuclear polymorphism, Mitoses and Cellular response) were evaluated and scored on a three-point scale. Total points of each case in this series were distributed from 4 to 10 points and divided into three classes: low grade malignancy (4-6 points), middle grade (7-9 points) and high grade (10-12 points).

The high grade malignancy cases indicated poor prognoses compared with those of low grade. Differentiation of tumor cell may be a significant factor in determining histological grade of malignancy has been suggested.
\end{abstract}

Key words: oral squamous cell carcinoma, histological factors, prognosis

\section{はじめに}

近年, 頭顓部扁平上皮癌の予後については, 腫瘍発生 部位, 進展度などの因子に加えて組織学的因子が重要で あることが指摘されてきた

長崎大学菌学部口腔外科学第 2 講座 （主任：井口次夫教授）

* 長崎大学歯学部口胵外科学第 1 犝座 （主任：佐々木元賢教授）

** 長崎大学口腔病理学讙座 （主任：岡遥治男教授）

Second Department of Maxillo-facial and Oral Surgery, Nagasaki University, School of Dentistry (Chief: Prof. Tsugio Inokuchi)

* First Department of Maxillo-facial and Oral Surgery, Nagasaki University, School of Dentistry (Chief: Prof. Motomasa Sasaki)

** Department of Oral Pathology, Nagasaki University, School of Dentistry (Chief: Haruo Okabe)

受付日：昭和59年 8 月 17 日
著者らは，口腔領城扁平上皮虫 1 次症例の初影時生検 材料により，組織学的悪性度を決定し，予後との関連に ついて検討を行ったので報告する.

\section{対}

昭和 52 年 10 月より，昭和 57 年 9 月までの 5 年間に長崎 大学医学部附属病院第 2 齿科口腔外科および長崎大学齿 学部附属病院口腔外科を受診した口腔領域扁平上皮的 1 次症例を対象とした。

上記期間における 口腔領域悪性腫場 1 次症例は 57 例 で，組織型別分類では扁平上皮癌は84.2\%を占めていた (表1).

\section{調査 方 法}

\section{1. 臨床的検討}

TNM 分類は国䏅対癌連合 (UICC) による 1978年の 分類 ‘)用いた，上顠洞については，1967年日本頭頸部 腫煌研究会の提唱した JJC 案 ${ }^{10)}$ を用いた. 生存率につ いては，予後観察期間が短いため，すへてて保険統計法 ${ }^{11}$ 
表 1 組制型に上る分数

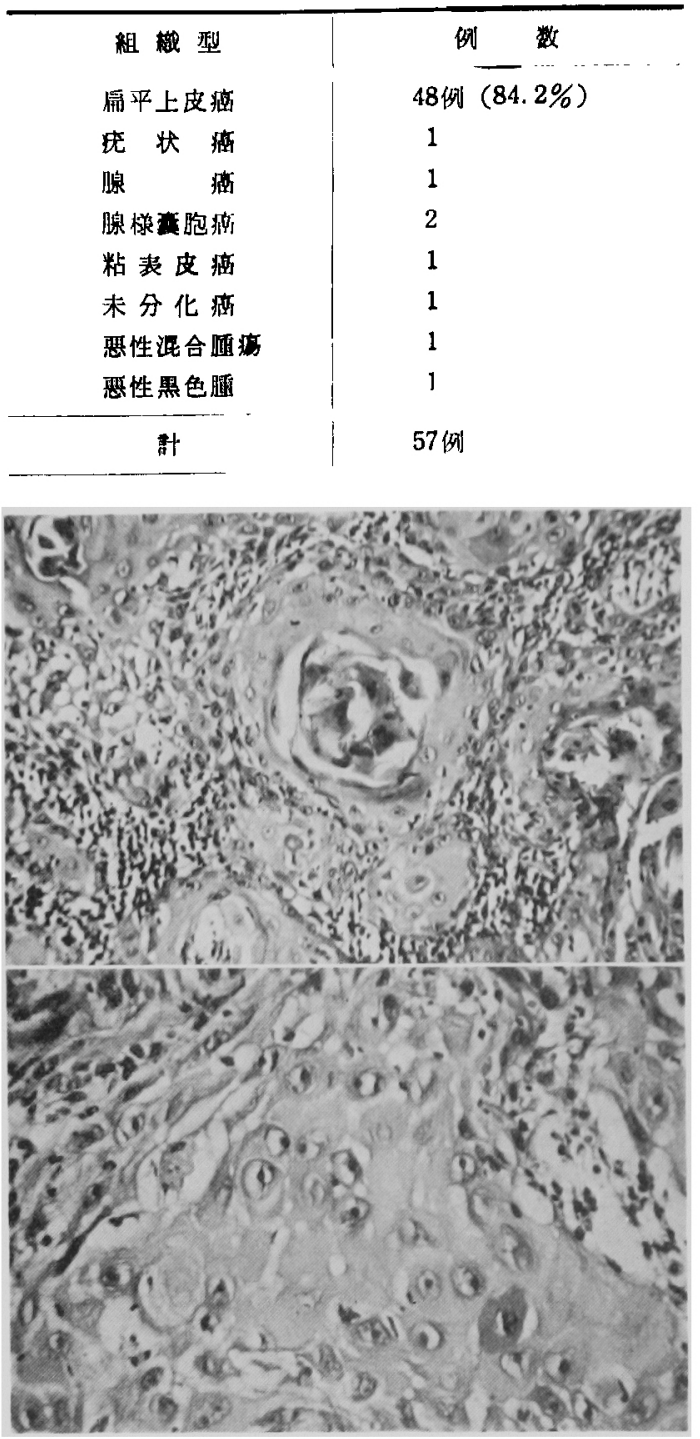

写真 1 症例番号 1 ：低悪性度群 (

分化度：高 $(ス コ フ 1)$ ，核異型度：軽度（スコフ 1)，核分裂像：少 $($ スフ 1$)$ ，細胞反応：著明 ( $x=>1$ )

上: $(\mathrm{H}-\mathrm{E}, \times 100)$, 下 $:(\mathrm{H}-\mathrm{E}, \times 400)$

を用いた。

\section{2. 組織学的検討}

口腔領域扁平上皮癌48例中，資料の整った46例の初猃 時生検材料について1971年の Jakobsson の分類 ${ }^{5} の 一$ 部 を用いて，組織学的悪性度の検討を行った。すなわち，

（1）分化度，（2）核異型度，（3）核分裂像，(4) 細胞反 応の程度を表 2 に示すように，それぞれ 3 段階に分類し

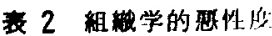

\begin{tabular}{|c|c|c|c|}
\hline $\begin{array}{r}x=7 \\
0\end{array}$ & 1 & 2 & 3 \\
\hline 1. 分化化) & (高明) & $\begin{array}{c}\text { 中笋度 } \\
\text { (少) }\end{array}$ & 倠) \\
\hline $\begin{array}{l}\text { 2. 核县型应 } \\
\text { 3. 核分裂像 }\end{array}$ & 业紧 & $\begin{array}{l}\text { 中等度 } \\
\text { 中等度 }\end{array}$ & 素度 \\
\hline 4. 科胞反芯 & 著 明 & 轱 度 & 恕 \\
\hline
\end{tabular}

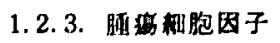

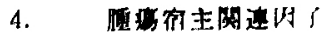

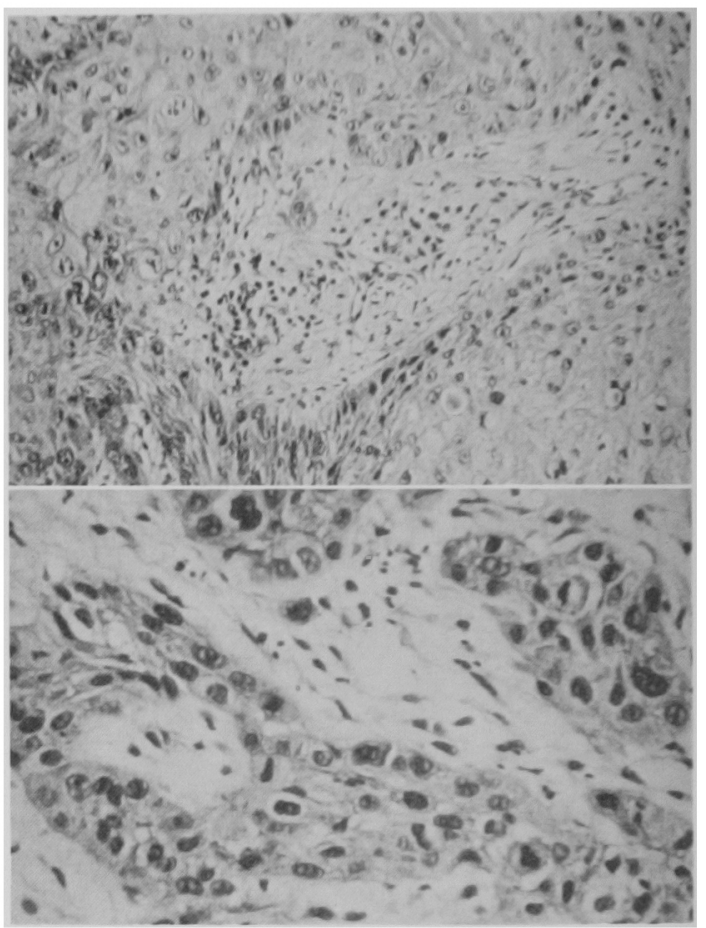

写高 2 症例番号 3 : 中等度悪性度群 (スコフ9) 分化度：中等度 $(x \neg 72)$, 核翼型度：中等度 ( コ 72$)$, 核分裂像: 多 $($ ス 73$)$, 梱胞反店: 軽 度 $($ ス $=72)$ 上: $(\mathrm{H}-\mathrm{E}, \times 100)$, 下: $($ H-E. $\times 400)$

(写】 1-上下，2-上下， 了-上下)，そのスコフの合計点 数と予後との関連性について検討を行った。なお，畽湯 細胞の構造㧍よび腫疸宿主境界における浸潤様式につい ては，今回の検索からは除外した。 また，核分裂像につ いては，400 倍の拉大率で，5視野中の核分裂像数 4 以 下をスコフ 1 (少)，5〜10をスコフ 2 (中等度)，11以 上をスュフ 3 (多) とした. 各組織学的判定基準の総加 算値は 4〜12 点にわたるが，4〜6 点を低悪性度群, $7 \sim 9$ 点を中等度悪性度群, 10 点以上を高悪性度群とし 


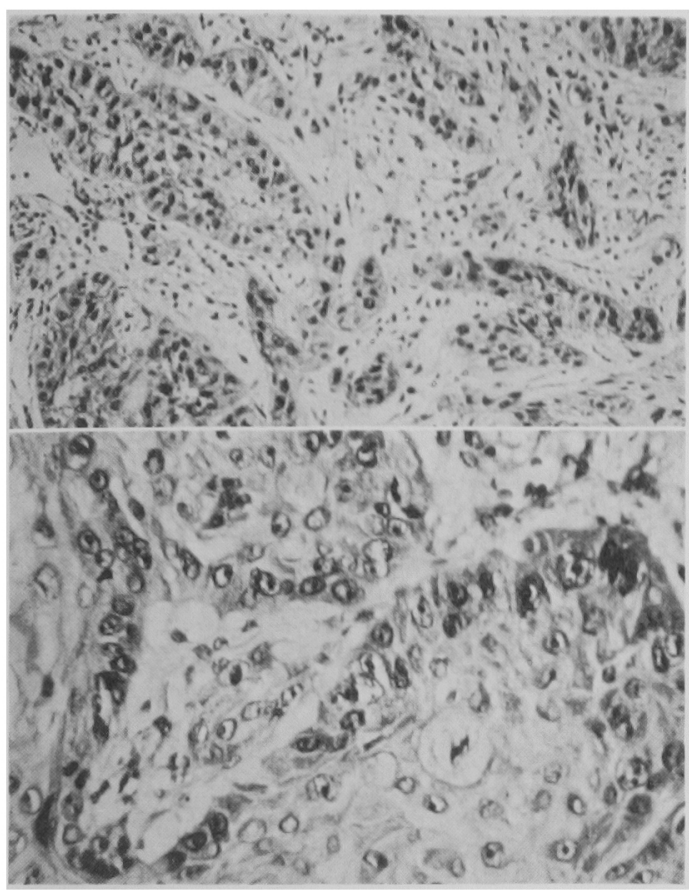

写真 3 症例番号 40：高悪性度群 ( スコア10)

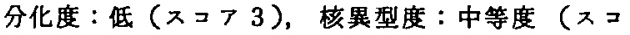
フ2），核分裂像：多（スコフ3），稩胞反応：軽度 ( $ス コ>2)$

上: $(\mathrm{H}-\mathrm{E}, \times 100)$, 下: $(\mathrm{H}-\mathrm{E}, \times 400)$

た. 以上の組緎学的所見と予後との関連について検討を 加党た.

結 果

\section{1. 臨床的検討}

1) 性別札よび年㱓別分布（表 3）

男性 33例，女性 15 例で男性に多く，男女比は 2.2:1 であった，年呤別分布では，50〜70代に多く，最年少者 は22歳女性，最高踰者は89歳男性であった。

2) 発生部位別分類（表 4)

腫境発生部位では, 舌が19例 (39.6\%) と最も多く, 次いで下䫇歯肉11例 (22.9\%)，上䫇歯肉 5 例 $(10.4 \%)$ で，以下，頓粘膜，上顎洞各 4 例，口底 3 例，下唇，軟 口蓋はそれぞれ1例であった，部位よりみた男女別発生 頻度では，㐘肉，上顎洞，口底および舌では男性が多 く、頓粘膜では男女同数であった。

3） TNM 分類 (表 5)

$\mathrm{T}$ 分類では， $\mathrm{T} 1: 5$ 例， $\mathrm{T} 2: 17$ 例, $\mathrm{T} 3: 23$ 例, $\mathrm{T}$ 4：3例であった，N分類ではN $0 か ゙ 31$ 例と王倒的に多 く，以下，N1：12例, N3： 4 例, N2：1 例の順であ った．全症例いずれるM0であった。

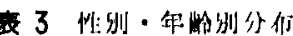

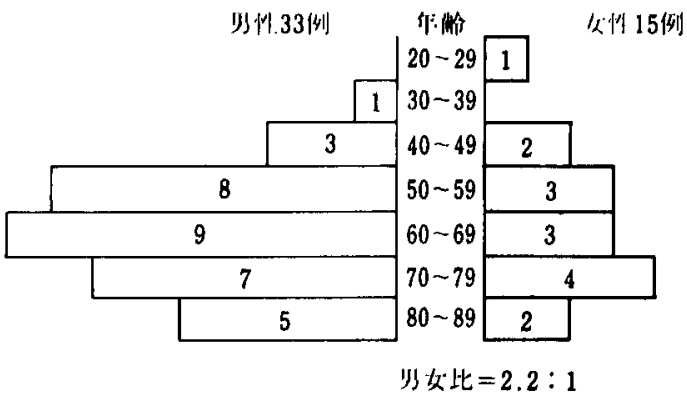

表 4 部位则分頪

\begin{tabular}{|c|c|c|c|}
\hline 部 位 & 例 数 & 男 性 & 女 性 \\
\hline 舌 & $19(39.6)$ & 11 & 8 \\
\hline 下額踭肉 & $11(22.9)$ & 10 & 1 \\
\hline 上影橉肉 & $5(10.4)$ & 2 & 3 \\
\hline 頪 粘 脱 & $4(8.3)$ & 2 & 2 \\
\hline 上影 洞 & $4(8.3)$ & 3 & 1 \\
\hline 口 店 部 & $3(6.3)$ & 3 & 0 \\
\hline 下 口居 & $1(2.1)$ & 1 & 0 \\
\hline 軟口藍 & $1(2.1)$ & 1 & 0 \\
\hline 計 & 48 例 $(100 \%)$ & 33 例 & 15 例 \\
\hline
\end{tabular}

表 5 TNM 分類

\begin{tabular}{|c|c|c|c|c|c|}
\hline$T^{N}$ & No & N 1 & $\mathbf{N} 2$ & N 3 & 計 \\
\hline $\mathbf{T}_{1}$ & 5 & & & & 5 \\
\hline $\mathbf{T} 2$ & 12 & 4 & & 1 & 17 \\
\hline T 3 & 12 & 8 & & 3 & 23 \\
\hline $\mathrm{T} 4$ & 2 & & 1 & & 3 \\
\hline 計 & 31 & 12 & 1 & 4 & 48例 \\
\hline
\end{tabular}

病期分類

\begin{tabular}{rrr} 
stage & I & 5 \\
& II & 12 \\
III & 24 \\
IV & 7 \\
\hline 計 & 48 例
\end{tabular}

stage 分類では, stage I : 5 例, II : 12 例, III :24 例， $\mathbb{V}: 7$ 例であり， stage $\mathbb{I}+\mathbb{N}$ の進行癌は 31 例で $64.6 \%$ 占めていた。

4) 治療方法について（表 6)

病期と治療方法との関係を表 6 K示した。当科に祘け る 1 次症例に対する治療方法は原則として，手術を主体 
衰 6 病期と治法方法との的保

\begin{tabular}{|c|c|c|c|c|c|}
\hline 治琶内容 & stage I & II & III & IV & 踖 \\
\hline C & & 1 & & & 1 \\
\hline $\mathbf{C}+\mathbf{S}$ & 2 & 1 & $2(1)$ & & $5(1)$ \\
\hline $\mathbf{C}+\mathbf{S}+\mathbf{R}$ & 3 & $6(2)$ & $14(5)$ & 1 & $24(7)$ \\
\hline $\mathbf{C}+\mathbf{R}$ & & $2(1)$ & $6(3)$ & $5(4)$ & $13(8)$ \\
\hline 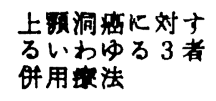 & & $2(1)$ & 2 & $1(1)$ & $5(2)$ \\
\hline 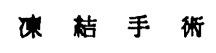 & & 2 & $1(1)$ & $1(1)$ & $4(2)$ \\
\hline 全垔部鄅消 & & & $7(3)$ & 1 & $8(3)$ \\
\hline 部分的影部郭海 & 1 & 2 & 5 & & 8 \\
\hline
\end{tabular}

$\mathbf{C}$ : 化学法, $\mathbf{S}:$ 手政, $\mathbf{R}$ : 故射線法（）内无亡

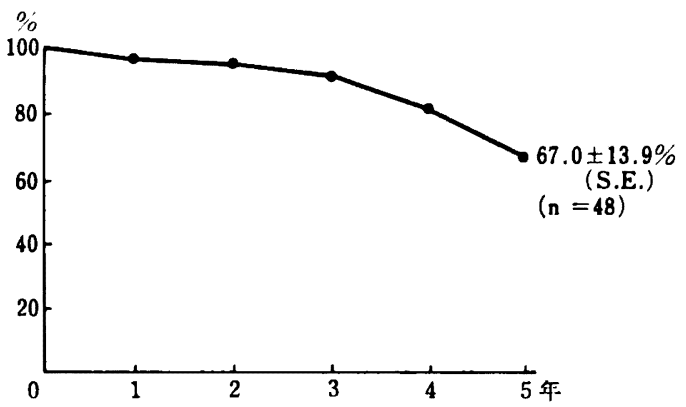

图 15 年累程生存事

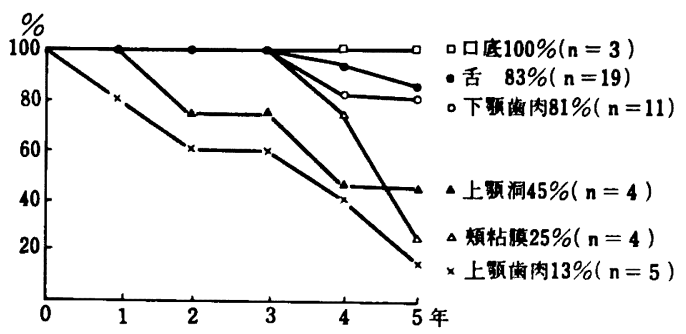

图 2 部位別 5 年累程生存禹

とし, 化学療法, 放射線庴法, 免疫療法を䔔宜併用し た.しかしながら, stage IV の進展例で手術不能例や手 術拒否例に 対しては, 化学宷法と放射線療法を併用し た.

5）生存率について

扁平上皮癌全症例の 5 年累積生存率は $67 \%$ であった (図1).

部位別 5 年累積生存率 では, 口底 $(100 \%)>$ 舌 (83 $\%)>$ 下罘因 $(81 \%)>$ 上額洞 $(45 \%)>$ 頓粘膜 $(25$ $\% ）>$ 上䫑齿肉 $(13 \%)$ の順であった（図 2 ).

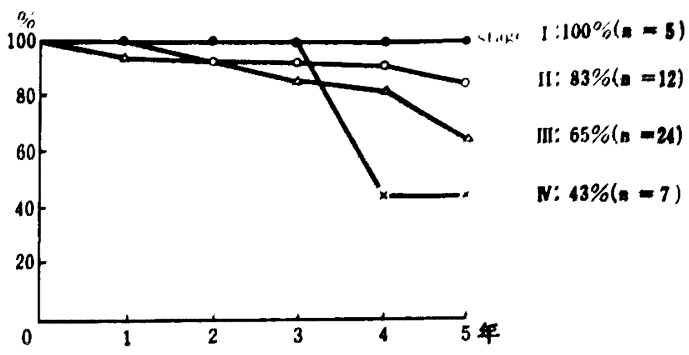

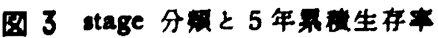

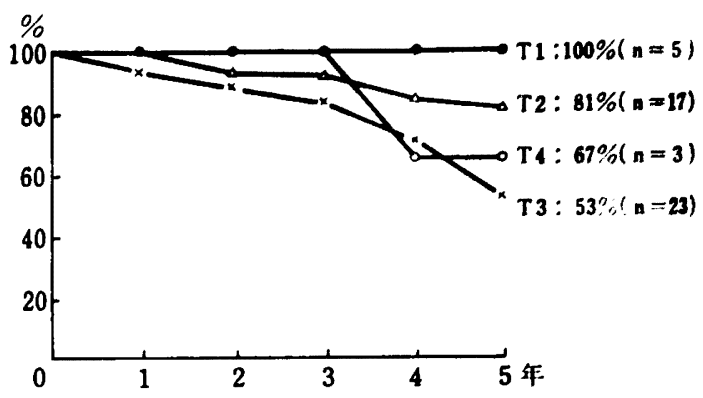

因 4 T分顉と 5 年罢积生存事

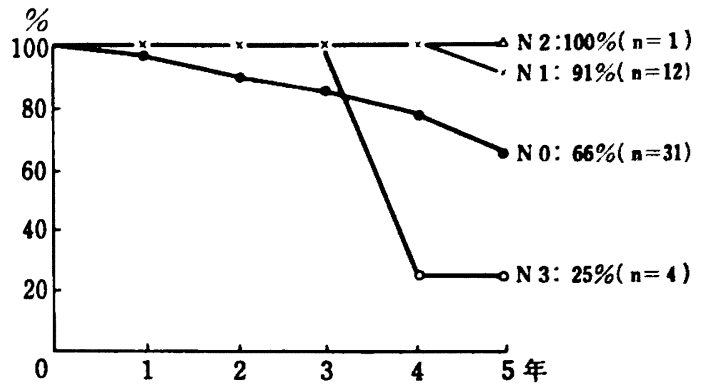

因 5 N分禎と 5 年罢积生存本

stage 分類と 5 年果積生存事の関俰は, stage I：100 $\%$, II : 83\%, I : 65\%, IV :43\%であり, 病期の進行 К伴い，生存炗が低下する㑯向がみられた（因了）.

TNM 分頼と 5 年累㛭生存率については， T 分頪で は, T1: 100\%, T2:81\%, T3:53\%, T4:67\%で あり，T3，T4群において，生存率の低下がみられた (図4).一方， N 分頼では，N $0: 66 \% ， \mathrm{~N} 1: 91 \%$, N2 : 100\%，N3：25\%であった（因 5 ）.

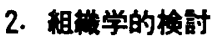

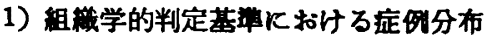

各症例こ゚とに，スコアの合計を求めろと，最低 4 点か ら最高10点まで分布したが，組織学的判定基整における 症例分布をみると（表 7)，分化度については，46 例中 37例 (80.4\%) がスコア1（高分化型扁平上皮蕰）であ った.これに対し，低分化型，スコフ 3 は 4 例 (8.7\%) に過ぎなかった。 
核䧼度については，その高度なスコフ3は5 例 (10.9\%) であった.

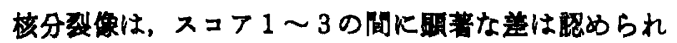
なかった.

細胞反沁は32例（69.6\%）においてて变明であった。

次比，核異型度，核分裂像および細胞反応の 3 つの因 子について，それぞれ分化度との成連をみると，变 8 の 結果となった，すなわち，分化度が高度な应例は核具型 度の轱いすのが多く，一方，分化度の低い应例では校興 型度は中等度から高度であった。

分化度と核分裂像との成俰においては，分化度が高度 な场合，核分裂像が少ないすのが多く，これに対して分 化度が低い症例では，核分裂像が中等度以上であった。

さらK，分化度と細胞反応との成保をみると，分化度 が高い症例は細胞反応が高度であることが多かった，低 分化型の症例 4 例では，細胞反応著明 1 例，中等度 3 例 であった

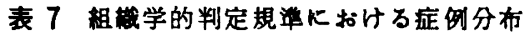

\begin{tabular}{r|r|r|r}
\hline スコフ & 1 & 2 & 3 \\
\hline 粗織学的判定基準 & 1 & 5 & 4 \\
\hline 1. 分 化 度 & 37 & 14 & 5 \\
2. 核 異 型 & 27 & 14 & 11 \\
3. 核 分 裂 & 21 & 13 & 1 \\
4. 梱 胞 反応 & 32 & \\
\hline
\end{tabular}

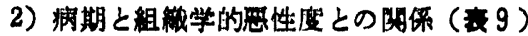

低覀性度啸（4６点）は46例中30例 (65.2\%) て， このろち、朝死は 8 例 (26.7\%) で, stage II, IV K みられた。

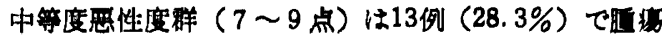
死は 6 例 (46.2\%) て， stage II，IVKみられ，stage IV では胹䏠死率は100\% であった。

高思性度群（10点）忙 3 侧 (6.5\%) で, stage II 2

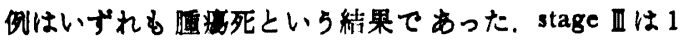
例て生存、近死峦は66.7\%であった。

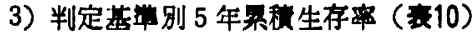

スコフ1とスコフ2+3群について娭时を行った，分

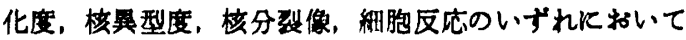
も、スコフ1の方がスコフ $2+3$ 群上りも生存高は高い 結果を示した。

4) 組織学的覀性度と 5 年累程生存率 (图 6)

5 年累程生存率は，低悪性度群 $72.4 \%$ ，中等度忽性度 群 $59.9 \%$ ，高悪性度群 $0 \%$ と，黑性度が高くなると，低 下する㑯向がみらた。

5) スコフ別生存年数 (因 7)

图 7 は，綖軸を生存年数，横軸をスコフの合計点数と し，各症例を生死别にフロットしたすのである．低悪性 度群 ( $4 \sim 6$ 点) で 2 年以内に死亡した症例は30例中, 7 例 $(23.3 \%)$ であった. 中等度思性度群（7～9 点） で 2 年以内死亡例は 13 例中 6 例 (46.2\%) であった．高 覀性度群 (10点) 3 例中 2 例は 2 年以内に死亡し， 1 例

表 8 核異型度，核分裂像，稩胞反応と分化度との関保

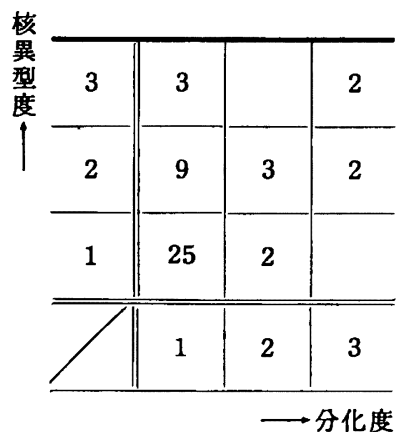

\begin{tabular}{|c|c|c|c|}
\hline 3 & 7 & 3 & 1 \\
\hline 2 & 9 & 2 & 3 \\
\hline 1 & 21 & & \\
\hline & 1 & 2 & 3 \\
\hline
\end{tabular}

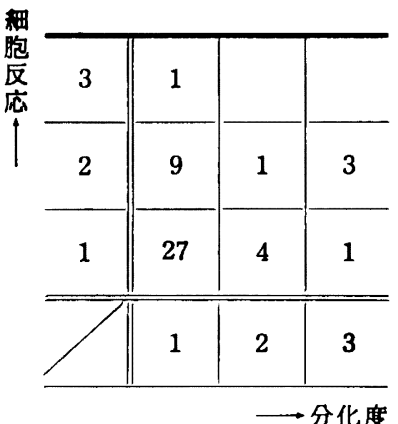

表 9 病期と組裁学的覀性度との関係

\begin{tabular}{|c|c|c|c|c|c|c|}
\hline 組䋨学的悪性度 & I & II & $\mathbb{I I}$ & $\mathbb{I V}$ & 合 計 & 腫薂死率 \\
\hline 低垔 性 度 群 & 5 & $7\left(1^{*}\right)$ & $15(6)$ & $3(2)$ & $30(9 * *)$ & $26.7 \%$ \\
\hline 中等度悪性度群 & & 2 & $8(3)$ & $3(3)$ & $13(6)$ & $46.2 \%$ \\
\hline 高悪 性 度群 & & $2(2)$ & 1 & & $3(2)$ & $66.7 \%$ \\
\hline
\end{tabular}

* 他因死 **1例他因死 


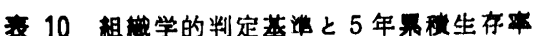

\begin{tabular}{|c|c|c|}
\hline 組溗学的判定基迹 & $ス コ フ$ & 5 年果敉生存种 \\
\hline \multirow{2}{*}{ 分 化 度 } & 1 & $69 \%(n=37)$ \\
\hline & $2+3$ & $42 \%(n=9)$ \\
\hline \multirow{2}{*}{ 核異型度 } & 1 & $73 \%(n=27)$ \\
\hline & $2+3$ & $50 \%(n=19)$ \\
\hline \multirow{2}{*}{ 核分裂做 } & 1 & $70 \%(n=21)$ \\
\hline & $2+3$ & $57 \%(n=25)$ \\
\hline \multirow{2}{*}{ 梱胞反応 } & 1 & $70 \%(n=32)$ \\
\hline & $2+3$ & $48 \%(n=14)$ \\
\hline
\end{tabular}

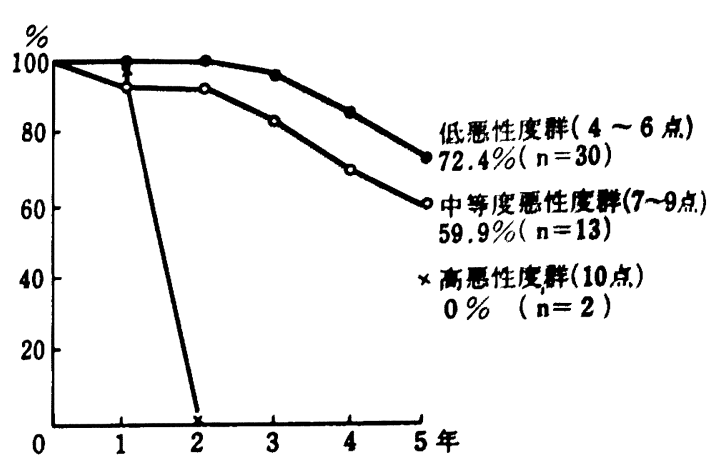

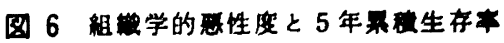

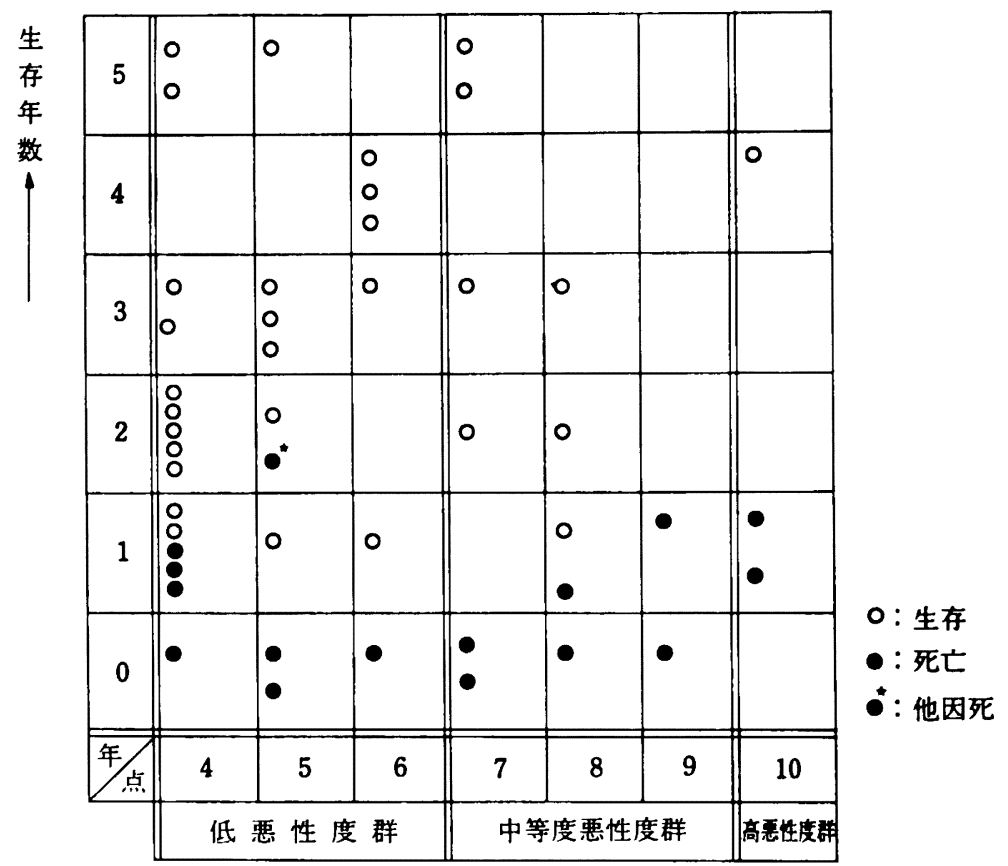

スコアおよU゙組糡学的悪性度

因7スコフ别生存年数

が生存中である. 次に低覀性度群における 2 年以内死亡 例 7 例と高悪性度群 3 例を表11，12に示した。

低悪性度群で早期死亡例はいずれも stage III，IVの進 行例であり, 症例番号23，45を除外すれば, 治療は手術 拒否例 3 例を含め, 化学療法と放射線療法の併用を行っ たが，いずれも原発巣の腫瘍抎大，あるいは頸部転移巣 の拡大浸潤が原因で死亡した，症例番号23は手術を行っ たが，術後肺炎を合併して死亡，また，症例番号45は， 舌部分切除ののち, 放射線照射を行ったが, 顒部リンハ
節に転移をきたし，その進行が急速なため，手術の時期 を逸した症例であった。

高覀性度群についてみると，症例番号 5 は 79 硆女性 で, 上顎洞癌 T $2 \mathrm{~N} 0 \mathrm{M} 0$, stage II で原発巣に対しい わゆる 3 者併用㞠法を行ったが, 治蒸抵抗性で, 13か月 後に原発巣の腫煬が払大し死亡. 症例番号 40 は 22 歳女 性, 舌癌 $\mathrm{T} 2 \mathrm{~N} 0 \mathrm{M} 0$, stage II で化学療法の徢, 舌部 分切除, 術後照射を行ったが, 10か月後, 碩部転移をき たした，さらに，全䫓部郭清，衍後黾子線照射を行った 
表 11 低苾性度群 2 年以内死亡例

\begin{tabular}{|c|c|c|c|c|c|}
\hline $\begin{array}{l}\text { 症例番号 } \\
\text { (年踏・性) }\end{array}$ & 部 位 & $\begin{array}{l}\text { TNM 分煩 } \\
\text { stage 分頪 }\end{array}$ & $x=7$ & 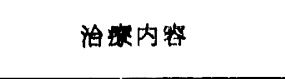 & 伍 \\
\hline$(71$, 女) & 上穎落肉 & $\begin{array}{c}\text { T } 3 \underset{\text { stage } \mathrm{N}}{\mathrm{N}} \mathrm{M} 0 \\
0\end{array}$ & 4 & $\mathrm{C}+\mathrm{R}+$ Cryosurgery & 1 年 6 か月㷋，膘倡再発し死亡 \\
\hline$(81$, , 男) & 下顥齿肉 & $\begin{array}{c}\mathrm{T} \\
\text { stage } \mathbb{I}\end{array}$ & 5 & $\mathbf{C}+\mathbf{S}$ & 堔後肺资を合併し死亡 \\
\hline$(62$, 女) & 煩 粘 膜 & $\begin{array}{c}\text { T } 3 \underset{\text { stage } \mathrm{N}}{\mathrm{N}} \mathbf{\mathrm { M }} 0 \\
0\end{array}$ & 4 & $\mathbf{C}+\mathbf{R}$ & 11か月後，近海死 \\
\hline (69, 男) & 上䫅 洞 & $\begin{array}{c}\mathrm{T} 4 \mathrm{~N} 0 \mathrm{M} 0 \\
\text { stage IV }\end{array}$ & 6 & $\begin{array}{l}\mathrm{C}+\mathrm{R}+\mathrm{S} \\
\text { いわゆる } \\
\text { 者併用站法 }\end{array}$ & 8 か月後，迎祝死 \\
\hline$(60$, 女) & 煩 粘 膜 & $\begin{array}{c}\text { T } 3 \underset{\text { stage }}{3} 0 \mathrm{M} 0 \\
0\end{array}$ & 4 & $\mathbf{C}+\mathbf{R}$ (手菜拒否) & 1 年 8 か月後, 随炶再哞し死亡 \\
\hline$(78$, 女) & 上影噒肉 & $\begin{array}{c}\text { T } 3 \underset{\text { stage }}{\mathbf{N}} 0 \mathrm{M} \\
0\end{array}$ & 4 & C+R（手政拒否） & 1 年10か月媵，国列再発，死亡 \\
\hline$(40$, 男) & 舌 & $\begin{array}{c}\text { T } \\
\text { stage } \\
\mathbf{N}\end{array} 0$ & 5 & $\mathbf{C}+\mathrm{S}+\mathrm{R}$ & 11か月挠, 顒部坛移, 死亡 \\
\hline
\end{tabular}

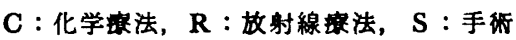

文 12 高悪性度群

\begin{tabular}{|c|c|c|c|c|c|}
\hline 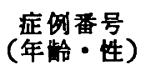 & 部 & $\begin{array}{l}\text { TNM 分類 } \\
\text { stage 分類 }\end{array}$ & $\pi=7$ & 治餈内容 & 枟 \\
\hline$(79$, 女 & 上 預 洞 & $\mathrm{T} \underset{\text { stage II }}{2 \underset{\mathrm{N}}{\mathrm{N}} 0 \mathrm{M}}$ & 10 & $\begin{array}{l}\mathrm{C}+\mathrm{R}+\mathrm{S} \\
\text { いわゆる } \\
\text { 者併用法 }\end{array}$ & 13か月後，贓死 \\
\hline$(22$, 女) & 舌 & $\begin{array}{c}\text { T } 2 \underset{\text { stage }}{2} \mathbb{N} 0 \\
0\end{array}$ & 10 & $\mathbf{C}+\mathbf{S}+\mathbf{R}$ & 1 年後, 到部転移 腫瘦死 \\
\hline $\begin{array}{c}16 \\
(54, \text { 男) }\end{array}$ & 上顎 洞 & $\underset{\text { stage III }}{3 \underset{N}{\mathrm{~N}} 0 \mathrm{M}} 0$ & 10 & 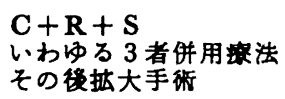 & $\begin{array}{l}\text { 生存（䛧後 } 4.5 \text { 年） } \\
\text { 再発・枟移 }(-)\end{array}$ \\
\hline
\end{tabular}

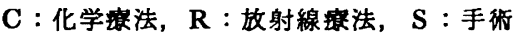

が, 顠部に再び転移巣を形成し， 1 年後死の伝帰をとっ た.

症例番号16は，上鿓洞癌 T $3 \mathrm{~N} 0 \mathrm{M} 0$, stage 田 症 例でいわゆる 3 者併用療法を行ったか;，原発巣に尰瘍残 存を認めたので，患側上顎に対し，払大切除術を行った

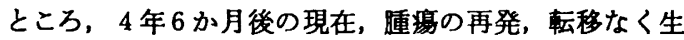
存中である.

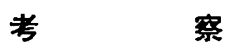

覀性腫湯の組織学的所見が治療方法の選択，ひいては 予後の推定を行らうえでの指標となりらるかとうかにつ いては，従来より関心が持たれてきた

組織学的所見と予後との関連を考える際, 組織学的所 見を客観的かつ普遍的に捉えることが，まず重要な課題 となる. Broders ${ }^{1,2)}$ は癌組織内における分化細胞と末分 化細胞の比率から，I〜IV度に分類し，臨床像との関連 について検討を行い, 腫場の組織学的因子研究の端緒と なった，1966年，Arthur 54は，角化度，核分裂像，異
型珄について，その程度に応じてスコアを㒃与し，それ

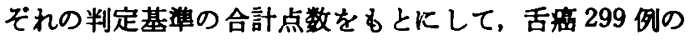
分析を行った。

1973年, Jakobsson 5 類を行い，搆造，分化度，核異型，核分裂像を腫晹細胞

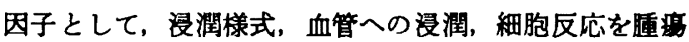
宿主関連因子として，おのおのの判定基潐に $1 \sim 4$ 点を 与え, その合計点数を組織学的悪珄度とし, 郜床像との 関連について報告した。

Jakobsson 55) の提唱する 8 因子を試験切除片で判定 する場合，深部の尰瘦宿主境界部を含んでいなければな らないか，当科における扁平上皮癌46例の初診時生検材 料の組織学的所見を検討したところ，試験切除片が小さ く, 構造, 浸潤様式について検索不可能な症例むあるた め, 上記因子を除外し，今回の検索では，(1) 分化度,

（2）核異型度，（3）核分裂像，（4）細胞反応の 4 因子に ついてスコアを与え, 予後との関連について検討を行っ た.

分化度については，高分化型が80.4\%を占め，これに 
対して，低分化型は $8.7 \%$ に過ぎず，尾崎ら”の竍告と 比較寸ると高分化型の占める比率は日：倒的に高加た。

次いで，分化度と他の 3 因子との成进をみると，核题

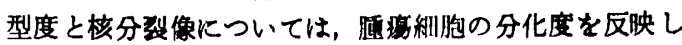
ている．細胞反応については，高分化型では著明なもの が多いか，中等度分化型と低分化型でも，中等度以上み られた，今回の模索に批いて，睡瘦細胞因子（分化度， 核異型度，核分裂像）間には，网連が惩められた。分化

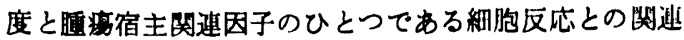

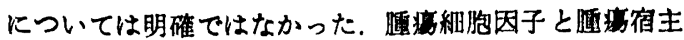
米速因子とは異なった概念引て捉えるべきかるしれな ᄂ.

分化度スコア1（高分化型）か低䍐性度群に占める割 合は73\%であった，一方，高䍐性度群 3 例をみると，い ずれす分化度はスコア3（低分化型）であった。

以上のことより，分化度は，組織学的墨性度を決定す る重要な因子と思われ，高分化型扁平上皮满の予後が良 好である(,7)ことに矛盾しない。

組織学的因子ごとにスコフ 1 と，スコフ 2，3 を合わ せた群について 5 年累筫生存率を比較したところ，スコ フ1は69〜73\%，スコフ2+3では42〜57\%と分化度, 核異型度，核分裂像および細胞反応の 4 因子について, 設定したスコフと生存率の間に関連が認められた。

組織学的悪性度と予後との夙連については，腫瘍死率 は，低，中，高悪性度群に㨟いてそれぞれ，26.7\%， $46.2 \%, 66.7 \%$ であり，5年累積生存率は， $72.4 \%$, $59.9 \% ， 0 \%$ 之覀性度が高くなるにつれ，予後は不良と なった。

低悪性度群における stage I + II 群の腫瘍死は0であ るのに対し, 高墨性度群では stage II の畽癁死率は 100 \%である. 高悪性度群に属する 3 例は，拡大手術が功を 奏したと思われる上額洞瘦の 1 症例を含め, いずれる治 療抵抗性であった。低，中等度悪性度群 の予後不良例 は, stage II, IV K集中しているのに対し, 高覀性度群 の予後不良例は病期にかかわりなく存在するよらであ り, 高覀性度群に対する治療の困難性を示唆しているよ 万に思われる。

今回, 組織学的悪性度を 倹索するために 用いた分化 度, 核異型度、核分裂像，細胞反応の 4 つの組織学的因 子は，単一の因子においても，その総合においても，腫 瘍の悪性度を反映し，予後との関連も詆められた。

以上のことより，初診時生検材料の 組織学的悪性度 は，早期に治療方針を計画するらえで指標となることが 示唆され, かつ, 予後の推定をるある程度可能にするの ではないかと思われた。

また，口腔領域扁平上皮癌症例の治療に際し，組織学 的悪性度を十分に把握して，低，中等度悪性度群飞打い ては，とくに stage $\mathbb{I I}, \mathbb{N}$ 症例に対して，また，高覀性 度群においては， stage にかかわることなく，即時再建

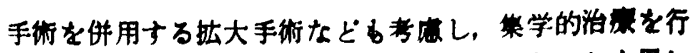
らことか，治䁈成模向上につながるのではないかと思わ れる.

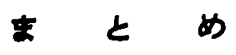

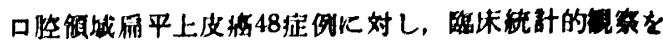
行った。 また46例の初秢封生娭材料上り，分化度，核县 型度，核分裂像扔上ひ，緗胞反心の 4 因子を用いて，组

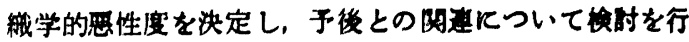
った.

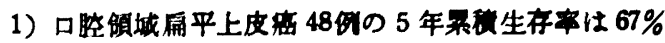
であった。

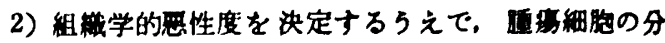
化度は自要な因子であると思われた。

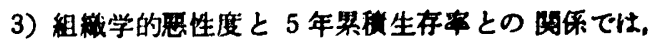

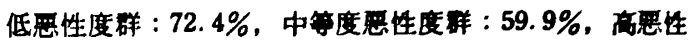
度群：0\%と，惫性度が高くなるとともに生存率俚低下 した.

4）高黑性度群においては、病期，発生部位にかかか りなく，予後不良例が存在するよらである。また，高息 性度群に対する治㫫の困嚾性が示唆された。

5）口腔颃城扁平上皮船の治噔に祭しては，初診時生 検材料の組織学的所見を十分に把提することが重要であ ると思われた。

本論文の要旨は，昭和58年第28回日本口貯外科学会公 会（於，東京）において器表した。

\section{引用文嗝}

1) Broders, A.C.: Squamous-cell epithelioma of the lip. A study of five hundred and thirtyseven cases. J Amer med Ass 74: 656-664 1920.

2) Broders, A.C.: Squamous-cell epithelioma of the skin. A study of 256 cases. Ann Surg 73: 141-160 1921.

3) Cade, S.S. and Lee, E.S.: Cancer of the tongue. A study based on 653 patients. Brit J Surg 44: 433-446 1957.

4) Arthur, J.F. and Fenner, M.L.: The influence of histological grading on prognosis in carcinoma of the tongue. (A computer analysis of 299 cases) Clin Radiol 17: 384-396 1966.

5) Jakobsson, P.A., Eneroth, C.M., et al.: Histologic classification and grading of malignancy in carcinoma of the larynx. Acta Radiol (Stockh.) 12: 1-8 1973.

6) Willen, R., Nathanson, A., et al.: Squamous cell carcinoma of the gingiva. Histological 
classification and grading of malignancy. Acta Otolaryngol 79: 146-154 1975.

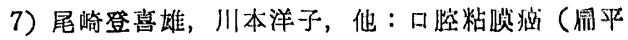
上皮癌）55例についての臨休的，病理租祴学的 検討。口科誌 29: 1-12 1979.

8）山本悦秀，砂川元，他：び漫性浸润型口腔皃 平上皮癌に関する矿究. 日口外詰 28：47-55 1982.

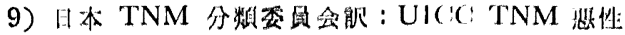

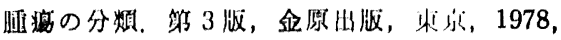
9-34

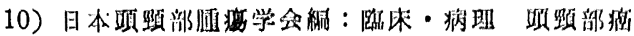

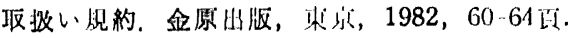

11) Cutler, S.J. and Edercr, F.: Maximum utilization of the life table method in analyzing survival. J Chron Dis 8: 699-712 1958. 